\title{
Comparative environmental impact evaluation using life cycle assessment approach: a case study of integrated membrane-filtration system for the treatment of aerobically-digested palm oil mill effluent
}

Yeit Haan Teow ${ }^{1,2^{*}}$, Meng Teck Chong ${ }^{1}$, Kah Chun $\mathrm{Ho}^{3}$ and Abdul Wahab Mohammad ${ }^{1,2}$

\begin{abstract}
Aiming to mitigate wastewater pollution arising from the palm oil industry, this university-industry research-anddevelopment project focused on the integration of serial treatment processes, including the use of moving bed biofilm reactor (MBBR), pre-treatment with sand filters and activated carbon filters, and membrane technology for aerobically-digested palm oil mill effluent (POME) treatment. To assess the potential of this sustainable alternative practice in the industry, the developed technology was demonstrated in a pilot-scale facility: four combinations (Combinations I to IV) of unit operations were developed in an integrated membrane-filtration system. Combination I includes a MBBR, pre-treatment unit comprising sand filters and activated carbon filters, ultrafiltration (UF) membrane, and reverse osmosis (RO) membrane, while Combination II excludes MBBR, Combination III excludes UF membrane, and Combination IV excludes both MBBR and UF membrane. Life cycle assessment (LCA) was performed to evaluate potential environmental impacts arising from each combination while achieving the goal of obtaining recycled and reusable water from the aerobically-digested POME treatment. It is reported that electricity consumption is the predominant factor contributing to most of those categories (50-77\%) as the emissions of carbon dioxide $\left(\mathrm{CO}_{2}\right)$, sulfur dioxide $\left(\mathrm{SO}_{2}\right)$, nitrogen oxides, and volatile mercury during the combustion of fossil fuels. Combination I in the integrated membrane-filtration system with all unit operations incurring high electricity consumption $(52 \mathrm{MJ})$ contributed to the greatest environmental impact. Electricity consumption registers the highest impact towards all life cycle impact categories: 73\% on climate change, 80\% on terrestrial acidification, 51\% on eutrophication, and $43 \%$ on human toxicity. Conversely, Combination IV is the most environmentally-friendly process, since it involves only two-unit operations - pre-treatment unit (comprising sand filters and activated carbon filters) and RO membrane unit - and thus incurs the least electricity consumption (41.6 MJ). The LCA offers (Continued on next page)
\end{abstract}

\footnotetext{
* Correspondence: yh_teow@ukm.edu.my

'Department of Chemical and Process Engineering, Universiti Kebangsaan

Malaysia, 43600 Bangi, Malaysia

${ }^{2}$ Research Centre for Sustainable Process Technology, Universiti Kebangsaan

Malaysia, 43600 Bangi, Malaysia

Full list of author information is available at the end of the article
}

(C) The Author(s). 2021 Open Access This article is licensed under a Creative Commons Attribution 4.0 International License, which permits use, sharing, adaptation, distribution and reproduction in any medium or format, as long as you give appropriate credit to the original author(s) and the source, provide a link to the Creative Commons licence, and indicate if changes were made. The images or other third party material in this article are included in the article's Creative Commons licence, unless indicated otherwise in a credit line to the material. If material is not included in the article's Creative Commons licence and your intended use is not permitted by statutory regulation or exceeds the permitted use, you will need to obtain permission directly from the copyright holder. To view a copy of this licence, visit http://creativecommons.org/licenses/by/4.0/. 
(Continued from previous page)

insights into each combination of the operating process and facilitates both researchers and the industry towards sustainable production.

Keywords: Life cycle assessment, Environmental impact, Integrated membrane filtration system, Palm oil mill effluent

\section{Introduction}

As the key driver for rural development in Malaysia, the palm oil industry provides direct employment to half a million Malaysians and indirect employment to another 250,000 people. The industry, however, has faced environmental challenges since the extraction of palm oil generates sizeable volumes of wastewater known as palm oil mill effluent (POME). The effluent is generally a thick, brownish colloidal suspension with not only a distinctively offensive odour, but also a high chemical oxygen demand $\left(15,000-100,000 \mathrm{mg} \mathrm{L}^{-1}\right)$ and a high biological oxygen demand $\left(10,250-43,750 \mathrm{mg} \mathrm{L}^{-1}\right)$ [1]. For every ton of fresh fruit bunch processed, $0.5-0.7 \mathrm{t}$ of POME is generated.

The release of untreated POME into water bodies causes environmental pollution by reducing the dissolved oxygen concentration therein, hence threatening the life of aquatic organisms $[2,3]$. Over the past few decades, POME has conventionally been treated with the use of a series of open ponds [4]. Nevertheless, this conventional biological treatment suffers from the emission of greenhouse gases (GHS), i.e., methane and carbon dioxide $\left(\mathrm{CO}_{2}\right)$ [5]. According to a report in 2009 by Roundtable on Sustainable Palm Oil, $70 \%$ of the GHS emitted from palm oil mills were attributed to POME. Accordingly, stringent legislation has been established against the release of untreated POME into water bodies. Besides, it is reported that $85 \%$ of water from the POME can be recycled, reducing the operating costs as well as to protect the environment from pollution [6]. A POME treatment system based on membrane technology shows high potential for eliminating the environmental problem, and in addition, this alternative treatment system offers water recycling [7]. The treated effluent has a high quality and crystal-clear water that can be used as the boiler feed water or as the source of drinking water production [8].
This study represents the research-and-development collaboration between university and the local palm oil industry to devise a practical strategy for the recycle and reuse of aerobically-digested POME. Aiming at improving sustainability in the palm oil industry, this industryuniversity project focused on the integration of the serial treatment process, including the use of the moving bed biofilm reactor (MBBR), pre-treatment through sand filters and activated carbon filters, and membrane technology for aerobically-digested POME treatment. The process flow of the unit operations is depicted in Fig. 1. The jointly-developed strategy was successful in achieving water recycle and reuse by treating the aerobicallydigested POME to attain the quality of boiler feed water [9]. Based upon the successful outcome, the resultant technology was demonstrated in a pilot-scale facility to assess the potential of this relatively sustainable alternative practice in the palm oil industry. Figure S1 of Supplemental Information depicts the piping and instrumentation diagram of the pilot-scale integrated membrane-filtration system.

The pilot-scale integrated membrane-filtration system consists of MBBR, sand filter and activated carbon pretreatment, coupled with ultrafiltration (UF) membrane, and reverse osmosis (RO) membrane. The pilot-scale integrated membrane filtration system has proven in enabling to treat aerobically-digested POME up to the standard where the treated water can be recycle and reuse as boiler feed water or any other usage [9]. Therefore, four combinations of unit operations in the integrated membrane-filtration system of pilot-scale were developed for treating the aerobically-digested POME to achieve the treatment target. Despite the success of this integrated membrane-filtration system in treating aerobically-digested POME and attaining recycled and reusable water, the potential environmental impacts by different combination of unit operations

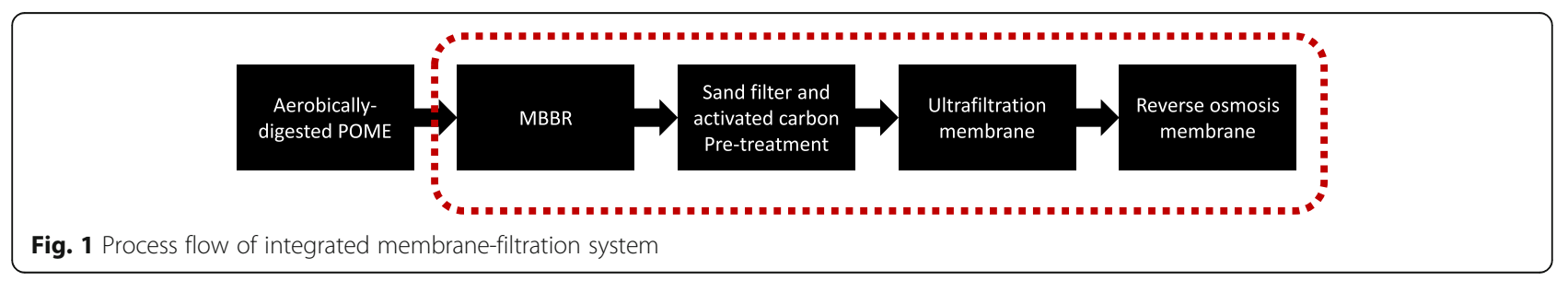


should be ascertained for the selection of most sustainable technology to implement in real industrial practice. Kamble et al. [10] reported that the use of MBBR in treatment plant had contributed to high $\mathrm{CO}_{2}$ and GHG emission due to high energy consumption by aerators or mechanical stirrers in ensuring the bed in MBBR is moving for uniform treatment. On the other hand, a study conducted by Meneses and Flores [11] stated that several critical environmental issues such as climate change, eutrophication, and human toxicity are linked to the high energy demand of membrane filtration system, namely UF and RO.

Life cycle assessment (LCA) is a viable tool to achieve an understanding on how the selected system can impact the environment. Sharvini et al. [12] has conducted a LCA of POME based energy generation and their findings provide useful information to guide decisionmakers in the sustainable management of POME. However, most of the previous studies only focus on single alternative in POME treatment technology [13-16]. Nevertheless, there is lack of LCA study towards pilotscale system in aerobically-digested POME treatment. Thus, there is a need to have an in-depth life-cyclebased model on pilot-scale integrated membranefiltration system in evaluating the potential environmental impacts imposed by each combination while achieving the goal of obtaining recycled and reusable treated water from aerobically-digested POME treatment. The LCA approach of comparing the aerobically-digested POME treatment technologies presented herein, and the findings are expected to offer impact-oriented insights into each combination of the operating process and to facilitate both researchers and the industry towards sustainable production.

\section{Methods}

In this study, the methodological framework for LCA by the International Standard Organization 14,040: 2006 was adopted to evaluate potential environmental impacts of the integrated membrane-filtration system through different combinations of unit operations. The methodology comprises four components: definition of goals and scope, life cycle inventory, assessment of life cycle impacts, and interpretation [17].

\section{Integrated membrane-filtration system Combination I}

Combination I of the integrated membrane-filtration system includes a MBBR, pre-treatment unit comprising sand filters and activated carbon filters, UF membrane, and $\mathrm{RO}$ membrane. The aerobically-digested POME accumulating in a clarified tank was pumped into a 500-L MBBR. Aeration was instituted through the use of an air compressor for $24 \mathrm{~h}$ throughout the biological treatment in the MBBR to ensure uniform distribution of the biofilm media [18]. The aerobically-digested POME was then pumped into an intermediate tank, passing through the pre-treatment unit and the UF-membrane unit. Subsequently, the pre-treated POME in the intermediate tank was further treated with the RO-membrane unit and left in a treated water storage tank.

Periodical chemical cleaning with $0.1 \mathrm{wt} \%$ sodium hydroxide $(\mathrm{NaOH})$ for a consecutive 2-h duration was performed to ensure the optimum performance of the UF- and RO-membrane units in first combination of the integrated membrane-filtration system after every cycle of membrane filtration $(6 \mathrm{~h})$ [7]. Chemical cleaning serves to remove fouling layer on the membrane surface ad is critical to the successful application of membrane technology. In this study, $\mathrm{NaOH}$ is used instead of hydrochloric acid $(\mathrm{HCl})$ due to its better cleaning performance [19].

\section{Combination II}

Combination II of the integrated membrane-filtration system includes a pre-treatment unit comprising sand filters and activated carbon filters, UF membrane, and RO membrane. The aerobically-digested POME accumulating in the clarified tank was pumped into the intermediate tank, passing through the pre-treatment unit and the UF-membrane unit, and bypassing the MBBR. Subsequently, the pre-treated POME in the intermediate tank was further treated with the RO-membrane unit and left in a treated water storage tank.

Similar to Combination I, periodical chemical cleaning with 0.1 wt\% $\mathrm{NaOH}$ for a consecutive 2-h duration was performed to ensure the optimum performance of the UF- and RO-membrane units in Combination II of the integrated membrane-filtration system after every cycle of membrane filtration (6h) [7].

\section{Combination III}

Combination III of the integrated membrane-filtration system includes an MBBR, pre-treatment unit through sand filters and activated carbon filters, and RO membrane. The aerobically-digested POME accumulating in the clarified tank was pumped into a 500-L MBBR. Aeration was instituted through the use of an air compressor for $24 \mathrm{~h}$ throughout the biological treatment in the MBBR to ensure uniform distribution of the biofilm media [18]. Unlike Combination I of the integrated membrane-filtration system, the aerobically-digested POME was pumped into the intermediate tank, passing through pre-treatment unit comprising sand filters and activated carbon filters and bypassing the UF-membrane unit. Subsequently, the pre-treated POME in the intermediate tank was further treated with the RO- 
membrane unit and left in the treated water storage tank.

Similar to Combination I of the integrated membranefiltration system, periodical chemical cleaning $0.1 \mathrm{wt} \%$ $\mathrm{NaOH}$ for a consecutive 2-h duration was performed to ensure the optimum performance of the RO-membrane units in Combination III of the integrated membranefiltration system after every cycle of membrane filtration (6h) [7].

\section{Combination IV}

Combination IV of integrated membrane-filtration system includes only pre-treatment through sand filters and activated carbon filters and a RO membrane. The aerobically-digested POME accumulating in clarified tank was directly pumped through the pre-treatment unit comprising sand filters and activated carbon filters and left in the intermediate tank, bypassing the MBBR and UF-membrane unit. Subsequently, the pre-treated POME in the intermediate tank was further treated with the RO-membrane unit and left in the treated water storage tank.

Similar to Combination I of the integrated membranefiltration system, periodical chemical cleaning with 0.1 wt\% $\mathrm{NaOH}$ for a consecutive 2-h duration was performed to ensure the optimum performance of UF- and RO-membrane units in Combination IV of the integrated membrane-filtration system after every cycle of membrane filtration $(6 \mathrm{~h})$ [7].

\section{Life cycle assessment \\ Goal and scope}

The goal and scope were defined at the early stage of the LCA to provide a clear purpose for the targeted audience [20]. System boundaries and functional units within the boundaries to achieve the desired goal are also clarified in this section [21].

The goal of this study is to conduct an environmental assessment for the integrated membrane-filtration system operating in different unit-operation combinations in aerobically-digested POME treatment. Among the three phases for the complete system (construction phase, operational phase, and disposal phase), only the second was considered in this study, given its greatest impact [22, 23]. Since only the operational phase is considered, the gate-to-gate approach is applied for the LCA. This signifies that the system boundary covers the operational units after the clarified tank including the MBBR, sand filters and activated carbon filters, UF membrane, and $\mathrm{RO}$ membrane. Figure 2 depicts the system boundaries for different combinations of the integrated membrane-filtration system. A volume of $6 \mathrm{~m}^{3}$ of boiler feed grade treated water was specified as the function unit (FU) of each system. $6 \mathrm{~m}^{3}$ was the capacity of the pilot-scale integrated membrane-filtration system. The selected FU was used as the basis for comparing the environmental impact imposed by different combinations of integrated membrane-filtration system. Quality of boiler feed grade treated water can be referred from our previous study [9].

\section{Life cycle inventory}

Life cycle inventory, the second stage in the LCA, is the most essential part where data collection is performed. In this study, data collection focused on the operational phase as explained in Goal and scope section. Three dominant inputs were elucidated for the integrated membrane-filtration system: electricity, chemical $(\mathrm{NaOH})$, and process water. Electricity was provided to the pump and air compressor to run the system during the treatment. Air was supplied to the MBBR to create a uniform circular movement for the biofilm growth. $\mathrm{NaOH}(0.1 \mathrm{wt} \%)$ was used for the chemical cleaning of the UF and RO membranes whereas process water was used for the backwashing of the sand filters and activated carbon filters. The life cycle inventories of the combinations for the integrated membrane-filtration system which collected from experimental data, relevant literature and environmental databases are summarized in Tables 1, 2, 3 and 4.

\section{Assessment of life cycle impacts}

Assessment of life cycle impacts at the third stage of the LCA is to identify and classify the potential environmental impacts imposed by different combinations of the integrated membrane-filtration system. The three basic elements in the assessment are category selection, classification, and characterization [24].

\section{Impact category selection}

SimaPro $^{\circ}$ v.8.4.0.0 LCA software used in this study contains a series of impact assessment methods: ReCiPe midpoint method, Centrum voor Milieukunde Leiden (CML) 2001 method, and environmental product declaration method [25]. Among them, the well-established ReCiPe midpoint method was chosen to facilitate this study [26]. ReCiPe method is selected as it is the updated method combining two popular methods [27], namely CML methodology and Eco-indicator 99 for the creation of broader impact categories [28]. Under ReCiPe method, the widely use midpoint evaluation is chosen to transform the life cycle inventory into a number of indicator scores $[29,30]$. Impact categories such as climate change, terrestrial acidification, human toxicity, and eutrophication were selected for assessment of life cycle impacts due to their close relation to the operational phase [17]. This is because the operational phase contributed significantly to the equipment's power 


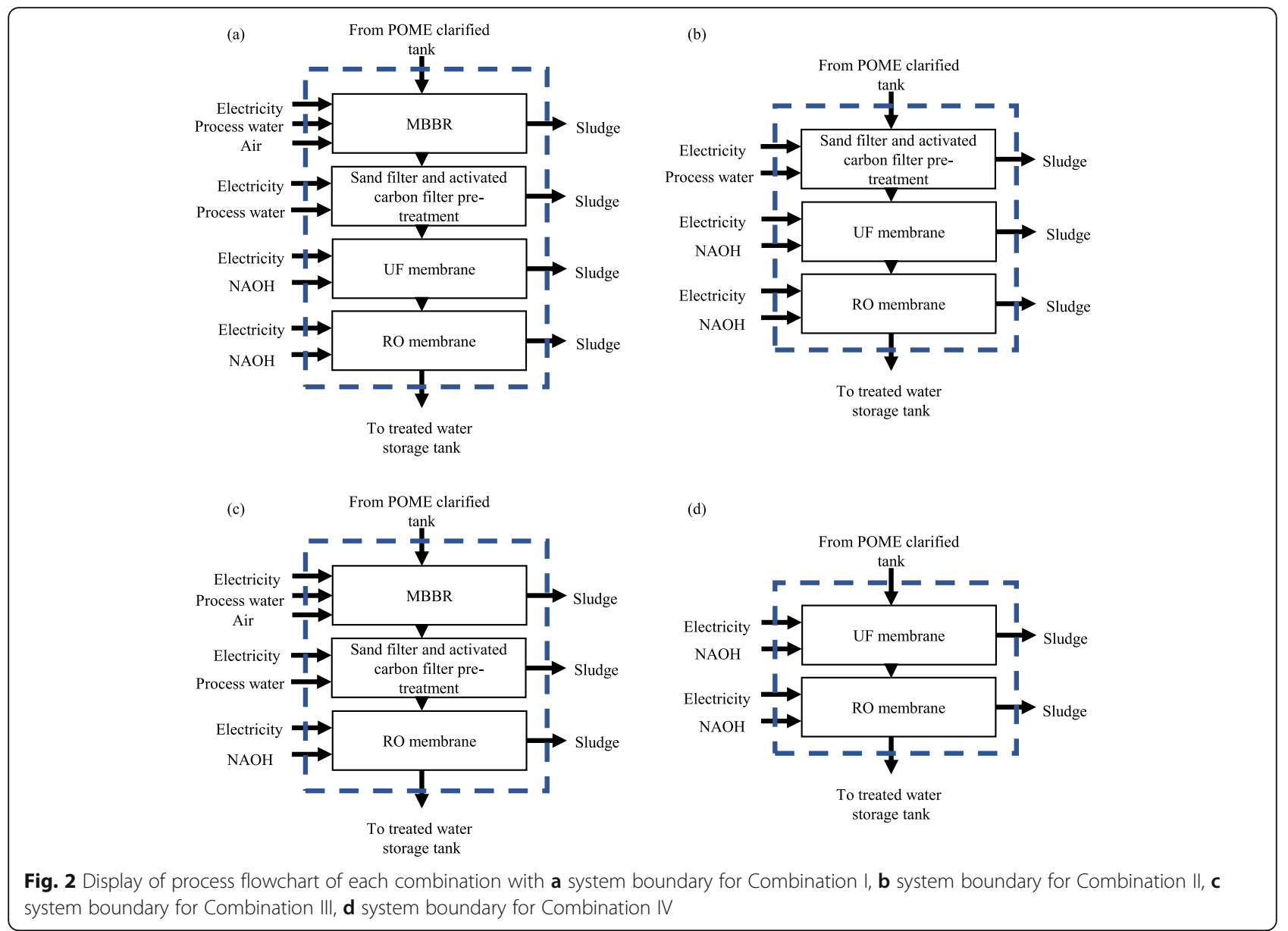

consumption hence impinging on the above impact categories strongly. In the study conducted by others [31, 32], climate change (global warming potential), acidification potential, and eutrophication potential are also being selected as the impact categories in the LCA study for aerobically-digested POME treatment.

\section{Classification}

Classification refers to the distribution of the data collected for the life cycle inventories to the life cycle impact categories [33]. In SimaPro v.8.4.0.0 LCA software, classification was computed automatically.

\section{Characterization}

Characterization refers to the distribution of the contributions of the data collected for life cycle inventories to the relevant life cycle impact categories. Components that contribute to the specific impact category were multiplied by the associated characterization factor. For characterization at the midpoint level in the ReCiPe midpoint method, characterization was determined through Eq. (1) [34].

$$
I_{m}=\sum_{i} Q_{m i} m_{i}
$$

where $m_{i}$ is the quantity of the substance released ( $\mathrm{kg}$ of substance $i), Q_{m}$ is the characterization factor connecting the quantity of the component with the selected impact category ( $\mathrm{kg}$ substance $\mathrm{i} / \mathrm{kg} \mathrm{CO}$ for climate change impact category), and $\mathrm{I}_{\mathrm{m}}$ is the displayed result showing the contribution of the component to the impact category ( $\mathrm{kg} \mathrm{CO}_{2}$ for climate change impact category).

However, the variation in characterization factor is inevitable. Thus, consistency in the development of midpoint and endpoint models in ReCiPe method was enhanced by working with the same time horizon per cultural perspective across the various impact categories, in order to ensure characterization factors are up-todate and representative for the global scale, while maintaining the possibility for a number of impact categories to implement characterization factors at a country and continental scale [35].

\section{Interpretation}

Interpretation is the last step in LCA. Assessment of the life cycle impacts is analyzed, compared, and discussed 
Table 1 Life cycle inventory of Combination I for integrated membrane-filtration system

\begin{tabular}{|c|c|c|}
\hline Unit operation/component & Unit & Amount \\
\hline \multicolumn{3}{|l|}{ (I) MBBR } \\
\hline Clarify water pump (P6102) & $\mathrm{kWh}$ & 2.24 \\
\hline Air compressor (IA6101) & kWh & 0.66 \\
\hline Air & $\mathrm{m}^{3}$ & 8.01 \\
\hline \multicolumn{3}{|l|}{ (II) Pre-treatment through sand filters and activated carbon filters } \\
\hline Biofilm transfer pump (P6103) & kWh & 1.12 \\
\hline Back wash pump (P6301) & kWh & 0.42 \\
\hline Process water & $m^{3}$ & 337.5 \\
\hline \multicolumn{3}{|l|}{ (III) UF membrane } \\
\hline Back wash pump (P6301) & $\mathrm{kWh}$ & 0.21 \\
\hline Process water & $\mathrm{L}$ & 168.75 \\
\hline $\mathrm{NaOH}$ & $\mathrm{kg}$ & 0.08 \\
\hline \multicolumn{3}{|l|}{ (IV) RO membrane } \\
\hline Intermediate transfer pump (P6303) & $\mathrm{kWh}$ & 1.12 \\
\hline High pressure pump (P6304) & kWh & 6.6 \\
\hline Intermediate transfer pump (P6303) -Chemical cleaning & $\mathrm{kWh}$ & 0.37 \\
\hline High pressure pump (P6304) - Chemical cleaning & kWh & 2.24 \\
\hline Process water & $\mathrm{L}$ & 168.8 \\
\hline $\mathrm{NaOH}$ & $\mathrm{kg}$ & 0.08 \\
\hline
\end{tabular}

for different combinations for the integrated membranefiltration system. The interpretation provides an impact relevant understanding on each combination of the operating process and facilitates both researchers and industry partners towards sustainable production.

Table 2 Life cycle inventory of Combination II for integrated membrane-filtration system

\begin{tabular}{|c|c|c|}
\hline Unit operation/component & Unit & Amount \\
\hline \multicolumn{3}{|c|}{ (I) Pre-treatment through sand filters and activated carbon filters } \\
\hline Biofilm transfer pump & kWh & 1.12 \\
\hline Back wash pump & $\mathrm{kWh}$ & 0.42 \\
\hline Process water & $m^{3}$ & 337.5 \\
\hline \multicolumn{3}{|l|}{ (II) UF membrane } \\
\hline Back wash pump & $\mathrm{kWh}$ & 0.21 \\
\hline Process water & L & 168.8 \\
\hline $\mathrm{NaOH}$ & $\mathrm{kg}$ & 0.08 \\
\hline \multicolumn{3}{|l|}{ (III) $\mathrm{RO}$ membrane } \\
\hline Intermediate transfer pump & kWh & 1.12 \\
\hline High pressure pump & $\mathrm{kWh}$ & 6.6 \\
\hline Intermediate transfer pump - Chemical cleaning & $\mathrm{kWh}$ & 0.37 \\
\hline High pressure pump - Chemical cleaning & kWh & 2.24 \\
\hline Process water & L & 168.8 \\
\hline $\mathrm{NaOH}$ & $\mathrm{kg}$ & 0.08 \\
\hline
\end{tabular}

\section{Results and discussion}

\section{Impact study of combination I}

As presented in Fig. 3a, Combination I portraited an interesting result where electricity consumption registers the highest impact towards climate change and terrestrial acidification. High contribution in eutrophication and human toxicity can be observed in both electricity consumption and process water. Among three dominant inputs for the Combination $\mathrm{I}, \mathrm{NaOH}$ contributed the least environmental impact regardless of the impact category.

The environmental impact on climate change is benchmarking with the release of $\mathrm{CO}_{2}$, the dominant GHS to the environment [36]. In Combination I, Fig. S2 shows that a total amount of $52 \mathrm{MJ}$ electricity was consumed for the treatment of partially-treated aerobicallydigested POME in obtaining $6 \mathrm{~m}^{3}$ of boiler feed grade treated water. The consumption of electricity for the treatment had released $12.7 \mathrm{~kg} \mathrm{CO}_{2}$, accounting for about $72 \%$ of the total $\mathrm{CO}_{2}$ release. As reported by the Malaysia Energy Commission [37], electricity generated in Malaysia originated from numerous sources: $90.7 \%$ from fossil fuels (comprising 50.4\% gas, 38.0\% coal, $1.1 \%$ oil, and $1.2 \%$ diesel), $8.4 \%$ from hydroelectricity, and $0.9 \%$ from others. Combustion of fossil fuels in power plants generates steam that drives turbines to produce electricity. Substantial amounts of $\mathrm{CO}_{2}$ released through such combustion have led to climate change. The Kyoto 
Table 3 Life cycle inventory of Combination III for integrated membrane-filtration system

\begin{tabular}{lll}
\hline Unit operation/component & Unit & Amount \\
\hline (I) MBBR & $\mathrm{kWh}$ & 2.24 \\
Clarify water pump & $\mathrm{kWh}$ & 0.66 \\
Air compressor & $\mathrm{m}^{3}$ & 8.0 \\
Air & $\mathrm{kWh}$ & 2.24 \\
(II) Pre-treatment through sand filters and activated carbon filters \\
Biofilm transfer pump & $\mathrm{kWh}$ & 0.56 \\
Back wash pump & $\mathrm{m}^{3}$ & 337.5 \\
Process water & \multicolumn{2}{l}{} \\
(III) RO membrane & $\mathrm{kWh}$ & 1.12 \\
Intermediate transfer pump & $\mathrm{kWh}$ & 6.6 \\
High pressure pump & $\mathrm{kWh}$ & 0.75 \\
Intermediate transfer pump - Chemical cleaning & $\mathrm{kWh}$ & 4.42 \\
High pressure pump - Chemical cleaning & $\mathrm{L}$ & 168.8 \\
Process water & $\mathrm{kg}$ & 0.16 \\
\hline NaOH
\end{tabular}

Protocol established by the United Nations Framework Convention on Climate Change supported the fact and stipulated that electricity generation has been one of the dominant factors contributing to the release of $\mathrm{CO}_{2}$ in Malaysia [38]. The RO membrane unit is the unit operation which utilizes the most electricity energy [39]. This is mainly due to the use of the high-pressure pump to provide the driving force across the $\mathrm{RO}$ membrane module.

In addition, the utilization of process water contributes fairly to climate change, accounting for about $27 \%$ of the total $\mathrm{CO}_{2}$ release. In Malaysia, surface water received by water-treatment plants is subjected to a series of treatment processes which incurs high electricity consumption and use of chemicals [40].

Table 4 Life cycle inventory of Combination IV for integrated membrane-filtration system

\begin{tabular}{lll}
\hline Unit operation/component & Unit & Amount \\
\hline (I) UF membrane & & \\
Back wash pump & $\mathrm{kWh}$ & 0.21 \\
Process water & $\mathrm{L}$ & 168.8 \\
$\mathrm{NaOH}$ & $\mathrm{kg}$ & 0.08 \\
(II) $\mathrm{RO}$ membrane & & \\
Intermediate transfer pump & $\mathrm{kWh}$ & 1.12 \\
High pressure pump & $\mathrm{kWh}$ & 6.6 \\
Intermediate transfer pump - Chemical cleaning & $\mathrm{kWh}$ & 0.75 \\
High pressure pump - Chemical cleaning & $\mathrm{kWh}$ & 4.42 \\
Process water & $\mathrm{L}$ & 168.8 \\
$\mathrm{NaOH}$ & $\mathrm{kg}$ & 0.16 \\
\hline
\end{tabular}

Despite $\mathrm{CO}_{2}$ release in electricity generation, the chemical reaction between coagulants and anions (such as $\mathrm{HCO}_{3}{ }^{-}$) could also contribute to $\mathrm{CO}_{2}$ formation [41]. The pre-treatment unit comprising sand filters and activated carbon filters is the unit operation which utilizes the most process water. This is because the coarse adsorbent in both filters required regular backwashing to ensure optimum operation [42]. On the other hand, $\mathrm{NaOH}$ exerts the least impact on climate change. It accounted for only $1.4 \%$ from the total $\mathrm{CO}_{2}$ release by both UF and $\mathrm{RO}$ membrane units due to the use of only minute amounts.

Figure S3 depicts the contribution of Combination I of the integrated membrane-filtration system towards terrestrial acidification. The environmental impact on terrestrial acidification is referred to as the release of sulphur dioxide $\left(\mathrm{SO}_{2}\right)$. As with the environmental impact category of climate change, electricity consumption exerts the greatest impact on terrestrial acidification, followed by process water and lastly by $\mathrm{NaOH}$. Other than $\mathrm{CO}_{2}, \mathrm{SO}_{2}$ is also emitted from the combustion of fossil fuels for electricity generation due to the oxidation of the sulphur content in coal while ammonia released to the atmosphere originates predominantly from agricultural activities $[43,44]$. These emissions lead to the acidic deposition of sulphuric acids, nitric acids, and ammonium in the ecosystems. In sensitive ecosystems, these acidic compounds will acidify the soil, affecting nutrient recycling and impacting ecological roles of the forests [45]. Therefore, it is not surprising that terrestrial acidification exhibits patterns similar to those of climate change.

Eutrophication arises from an oversupply of nutrients, most commonly as nitrogen, which leads to the overgrowth of plants and algae in the aquatic ecosystem [46]. Hence, the environmental impact on eutrophication is reflected by the release of nitrogen. As illustrated by Fig. S4, eutrophication is attributed appreciably to electricity consumption $(50 \%)$ and process water $(48 \%)$. Nitrogen oxides are released in two forms for electricity generation: fuel $\mathrm{NO}_{\mathrm{x}}$ and thermal $\mathrm{NO}_{\mathrm{x}}$. Fuel $\mathrm{NO}_{\mathrm{x}}$ is emitted during the burning of fossil fuels due to the combustion of coal and nitrogen-containing oil [47]. Thermal $\mathrm{NO}_{\mathrm{x}}$ is formed through the oxidation of nitrogen in atmospheric air at high temperatures [48]. The release of nitrogen oxides to the environment, especially into water bodies, causes algae booming and culminates in eutrophication. The RO membrane unit, which utilizes the most electricity energy, is the dominant unit operation unit leading to eutrophication.

Comparatively, process water contributes towards eutrophication to a larger extent (48\%) than towards climate change and terrestrial acidification. The underlying reason is that, other than the formation of nitrogen 


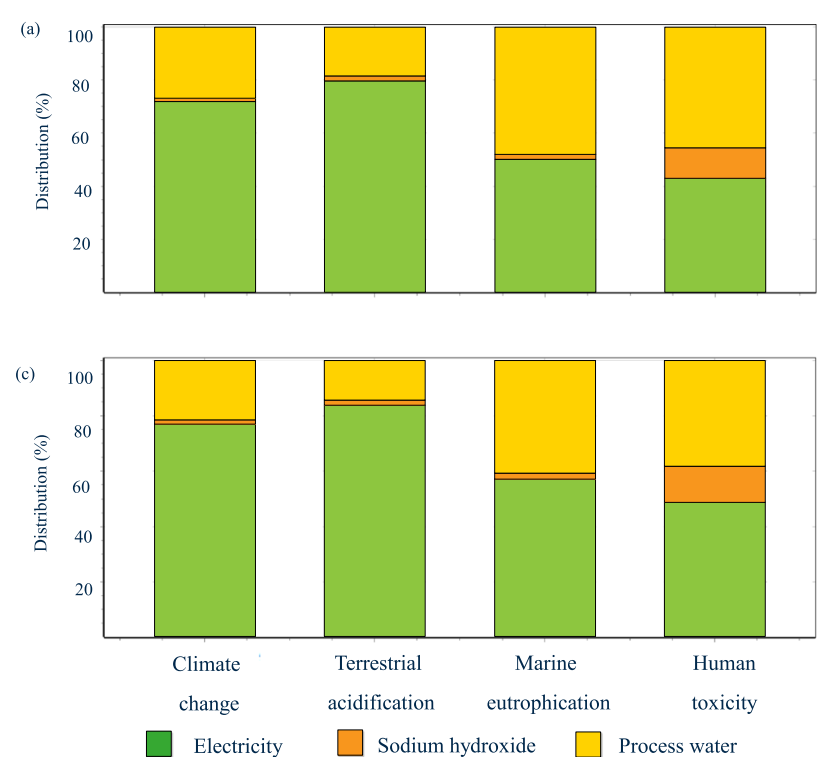

(b)

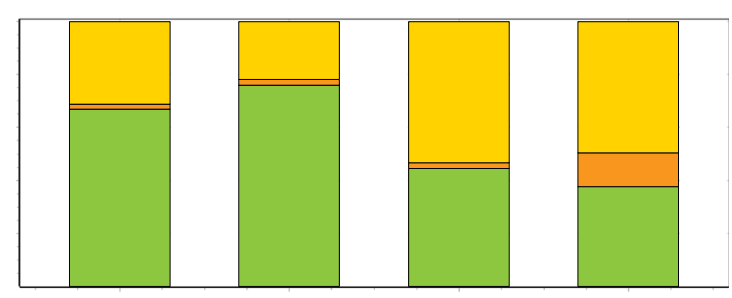

(d)

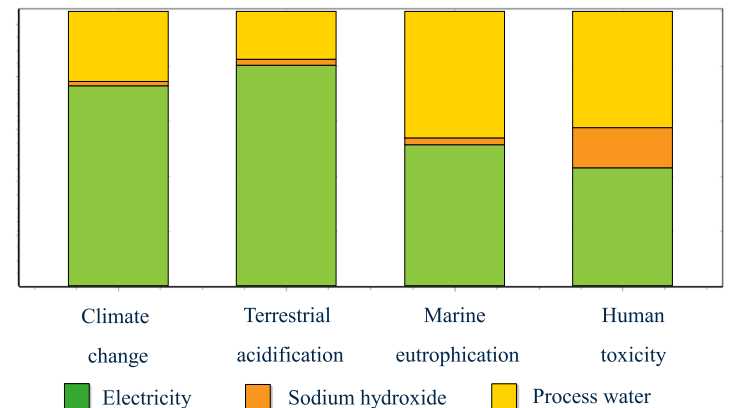

Fig. 3 Distribution of life cycle impact categories contributed by a Combination I of integrated membrane-filtration system, b Combination II of integrated membrane-filtration system, c Combination III of integrated membrane-filtration system, $\mathbf{d}$ Combination IV of integrated membrane-filtration system

oxides caused by electricity utilization in watertreatment plants, chlorination - the commonly-applied disinfection process in Malaysia's water-treatment plants [49] - also plays a role. A shortcoming of chlorine is that it may react with organic matters and rust deposited on surfaces of pipes [50]. This leads to the release of ammonia into the environment: when leached into water bodies, such ammonia will promote algae growth [51]. Expectedly, the pre-treatment unit comprising sand filters and activated carbon filters which utilizes large amounts of process water contributes appreciably to eutrophication.

Human toxicity can be observed in Fig. S5 where such toxicity is reflected by the impact of 1,4-dichlorobenze on human health [52]. As with eutrophication, human toxicity is attributed appreciably to electricity consumption (43\%) and process water (45\%). Process water registers the highest impact towards human toxicity mainly due to the release of mercury associated with the use of chlorine in water treatment plants for the production of process water. Chlorine is commonly produced with the use of mercury cells. As reported by the USEPA [53], $94 \%$ of chlorine produced in the United States originated from the mercury-cell process. The mercury used in the process has the potential to vaporize and be released into the environment [54]. The mercury thus released, upon entry into water bodies, will form a toxic substance known as methylmercury that threaten human [55]. As reported by Ayres [56], the mercury-cell process is the major source of the environment impact on human toxicity. Additionally, the generation of electricity likewise contributes to human toxicity. The combustion of fossil fuels for electricity generation emits toxic substances such as arsenic, mercury, and lead, which jeopardises human health [57]. These toxic substances will stay in the human body for long periods of time [58]. According to Hidayu et al. [59], as much as $26 \%$ of mercury emission resulted from the combustion of fossil fuels during electricity generation.

\section{Impact study of combination II}

Combination II portrays a similar trend as Combination I, where electricity consumption registers the highest impact towards climate change and terrestrial acidification. However, as opposed to Combination I, a greater impact on eutrophication and human toxicity can be observed in Fig. 3b, where environmental impact from process water occupied larger portion of the chart.

Presented in Fig. 3b, electricity consumption registers the greatest impact (67\%), followed by process water (31\%), and lastly by $\mathrm{NaOH}(2 \%)$. Combination II bypasses the MBBR as compared to Combination I; hence, less electricity was needed for the system operation. As presented in Fig. S6, as much as $41.6 \mathrm{MJ}$ of electricity was consumed for the treatment process in Combination II, contributing to $10.1 \mathrm{~kg}$ of $\mathrm{CO}_{2}$ release. Given its use of the high-pressure pumps, the $\mathrm{RO}$ membrane unit consumes the greatest amount of electricity and is thus the dominant unit operation contributing to climate change.

Additionally, process water contributes fairly to climate change. The pre-treatment unit comprising sand filters and activated carbon filters utilizes the most process water 
for regular backwashing. Therefore, the environmental impact of the pre-treatment unit toward climate change is undeniable. On the other hand, $\mathrm{NaOH}$ exerts the least impact on climate change, contributing to only $1.6 \%$ from the total $\mathrm{CO}_{2}$ release by both UF and $\mathrm{RO}$ membrane units due to the use of only minute amounts.

Similarly, electricity consumption registers the greatest impact on terrestrial acidification, as clearly stated in Fig. S7. Since it is due to $\mathrm{SO}_{2}$ emissions during the combustion of fossil fuels for electricity generation, terrestrial acidification exhibits patterns similar to those of climate change [60]. Besides, large amount of process water used in Combination II is the key reason to promote eutrophication (50\%), as depicted in Fig. S8. Approximately $675 \mathrm{~kg}$ of process water - equivalent to $0.00154 \mathrm{~kg}$ of nitrogen release - was utilized on the backwashing of the pre-treatment unit comprising sand filters and activated carbon filters, and on cleaning of the UF and RO membrane units, Nevertheless, the RO membrane unit contributes the greatest environmental impact towards eutrophication. This is because, other than consumption of process water for cleaning, the RO membrane unit also utilizes a high amount of electricity, contributing to the formation of nitrogen oxides which eventually leads to eutrophication.

As with eutrophication, process water registers the highest contribution towards human toxicity in Fig. S9. In this regard, the pre-treatment unit (which requires much process water for regular backwashing) is the unit operation predominantly contributing to human toxicity under the process water input. However, given its appreciable electricity consumption due to high-pressure pumps and moderate utilization of process water for membrane cleaning, the $\mathrm{RO}$ membrane unit is the unit operation contributing to the greatest environmental impact towards eutrophication in Combination II.

\section{Impact study of Combination III}

Combination III generally explicit a greater footprint on four impact categories studied. As shown in Fig. 3c, electricity consumption holds substantial amount of $77 \%$ on climate change, $84 \%$ on terrestrial acidification, $57 \%$ on eutrophication, and $49 \%$ on human toxicity. Process water exerts a moderate impact on all such impact categories: $22 \%$ on climate change, $15 \%$ on terrestrial acidification, $41 \%$ on eutrophication, and $38 \%$ on human toxicity. Lastly, $\mathrm{NaOH}$ exerts the least impact on all impact categories: $2 \%$ on climate change, $2 \%$ on terrestrial acidification, $2 \%$ on eutrophication, and $13 \%$ on human toxicity.

The contributions of Combination III of the integrated membrane-filtration system towards the environmental impacts are presented: climate change (Fig. S10), terrestrial acidification (Fig. S11), eutrophication (Fig. S12), and human toxicity (Fig. S13). Contributions of the three main dominant inputs concluded that electricity consumption is the main input factor leading to all environmental impacts imposed by Combination III. As much as $52 \mathrm{MJ}$ of electricity was consumed for the treatment process in Combination III, which exceeds that of Combination II $(41.6 \mathrm{MJ})$. Although Combination III bypassing the UF-membrane unit has reduced the use of electricity by the UF-membrane unit, the MBBR nonetheless consumes appreciable electricity due to continuous air supplied by the air compressor for the biofilm growth [61]. As electricity consumption is the main input factor leading to all environmental impacts imposed by Combination III, the RO membrane unit, with its use of high-pressure pumps, consumes the greatest amount of electricity and is thus the dominant unit operation promoting for aforementioned environmental impacts under operating processes in Combination III.

Besides electricity consumption, process water utilized in the integrated membrane-filtration system also exerts critical environmental impacts. In this regard, despite its utilisation of only little electricity, the pre-treatment unit comprising sand filters and activated carbon filters warrants copious process water for frequent backwashing. It therefore contributes appreciably to the environmental impacts of climate change, terrestrial acidification, eutrophication, and human toxicity. Comparatively, despite its utilisation of an equal amount of electricity, the MBBR contributes the least to environmental impact for all categories, since it does not require process water for its operation.

\section{Impact study of Combination IV}

As presented in Fig. 3d, electricity consumption contributes a total peak of $73 \%$ on climate change, $80 \%$ on terrestrial acidification, $51 \%$ on eutrophication, and $43 \%$ on human toxicity for the impact study of Combination IV. Moderate impact imposed by process water towards all the categories: $25 \%$ on climate change, $17 \%$ on terrestrial acidification, $46 \%$ on eutrophication, and $43 \%$ on human toxicity. Lastly, $\mathrm{NaOH}$ registers the least impact towards the categories: $2 \%$ on climate change, $2 \%$ on terrestrial acidification, $3 \%$ on eutrophication, and $15 \%$ on human toxicity.

The contributions of Combination IV of the integrated membrane-filtration system towards the environmental impacts are depicted: climate change (Fig. S14), terrestrial acidification (Fig. S15), eutrophication (Fig. S16), and human toxicity (Fig. S17). The three main dominant inputs contribution thus depicted concluded that electricity consumption is the main input factor leading to all environmental impacts imposed by Combination IV. Combination IV is more energy-saving (it consumed the least electricity, i.e., only $41.6 \mathrm{MJ})$ : the underlying reason 
is that it bypasses the MBBR and UF-membrane unit and instead involves only the pre-treatment unit (comprising sand filters and activated carbon filters) and RO membrane unit. Electricity consumption leads to all environmental impacts imposed by Combination IV. In this regard, the RO membrane unit with its use of highpressure pumps consumes more electricity than the pretreatment unit; thus, it is the dominant unit operation leading to the said environmental impacts. As with Combination III, the magnitudes of the environmental impacts for Combination IV are as follows: electricity consumption (greatest), utilization of process water (moderate), and lastly the use of $\mathrm{NaOH}$ (least).

\section{Application of life cycle assessment in decision making}

After individual assessment of four different combinations, it is crucial to conduct a comparative study for decision-making on system application for aerobicallydigested POME treatment. The comparative study for the combinations is presented in Fig. 4. Combination I exerts the greatest impact towards all life cycle impact categories, possibly due to its involvement of many unit operations and the consequential high electricity consumption, utilization of process water, and use of $\mathrm{NaOH}$. Generally, the contribution of system combination towards the categories followed the ascending sequence of Combination IV (least) $<$ Combination III $<$ Combination II $<$ Combination I (greatest), regardless the life cycle impact category attributed to the reduction of unit operation. However, the environmental impacts of climate change and terrestrial acidification imposed by Combination III are higher than those by Combination II. This is mainly due to higher electricity consumption of the MBBR in Combination III. As explained previously, $\mathrm{CO}_{2}$ released through the combustion of fossil fuels is the dominant factor leading to climate change [38]. Therefore, the high electricity consumption of the MBBR in Combination III registers a greater environmental impact towards climate change [62]. Likewise, terrestrial acidification is caused mainly by $\mathrm{SO}_{2}$ emissions during the combustion of fossil fuels [63]. Therefore, both climate change and terrestrial acidification exhibit the same trend.

On the other hand, despite electricity consumption, the two environmental impacts of eutrophication and human toxicity are also greatly affected by the utilization of process water. For the former, the release of ammonia into the environment through the reaction between chlorine in water and natural organic matters promote algae growth and culminate in eutrophication [64]. For the latter, the release of mercury during chlorine formation leads to its leaching into water bodies and thus the formation of toxic methylmercury that threatens human health [55]. Combination II (which involves the pretreatment unit) utilizes more process water for regular backwashing than Combination III (which bypasses the pre-treatment unit). Therefore, Combination II registers a high environmental impact to eutrophication. All in all, Combination IV of the integrated membranefiltration system is the most environmentally-friendly operating process for treating aerobically-digested POME in achieving $6 \mathrm{~m}^{3}$ of boiler feed grade treated water. Combination IV has reduced the electricity consumption by $20 \%$ which contributing to most of impact categories (climate change, terrestrial acidification, marine eutrophication, human toxicity) as the emissions of $\mathrm{CO}_{2}, \mathrm{SO}_{2}$, nitrogen oxides, and volatile mercury during the combustion of fossil fuels.

\section{Sensitivity analysis}

The results of the analysis of the four combinations of boiler feed water treatment systems explain that the use of electricity is a major factor contributing to the environmental impact. As such, further analysis has been made to compare the environmental impact of the existing electricity use in Malaysia with alternative energy

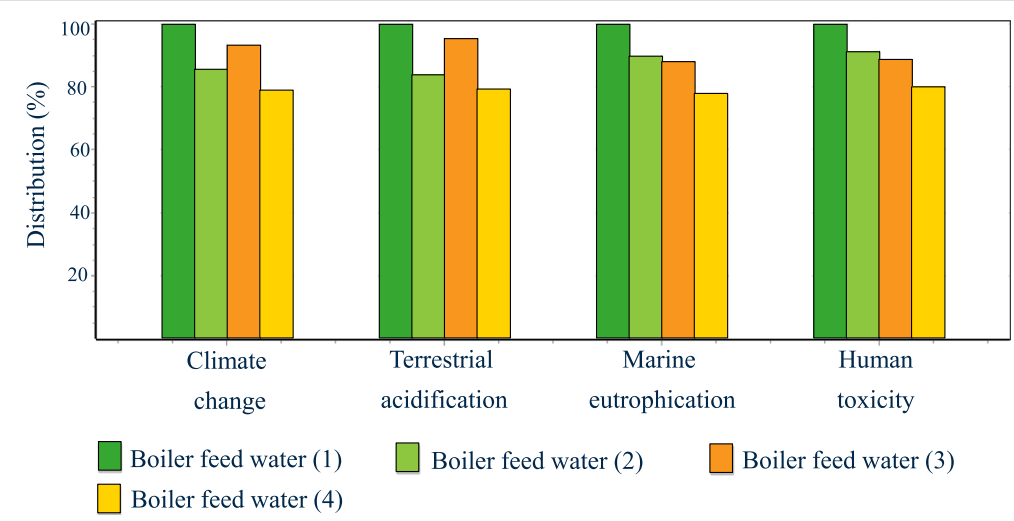

Fig. 4 Contribution of boiler feed water produced by each combination in integrated membrane-filtration system towards life cycle impact categories 
sources. Hydro power is a renewable energy source. Hydroelectric generation plant uses dams to store water from various sources. When the water flows and moves the turbine, the form of energy will convert from kinetic energy into mechanical energy. The turbine moves the generator rotor and transforms the mechanical energy into electrical energy [65]. In Malaysia, electricity generation with hydropower resources is still underdevelopment, as far it is only $8.4 \%$ hydroelectric in electricity generation [66]. However, alternative energy sources have begun to take over and play an important role in power generation [67]. According to International Energy Agency 2019, the demand for electricity from hydropower sources is increasing across Asia [68].

In addition, other alternative energy sources such as photovoltaic energy are also being considered. Photovoltaic (PV) is a method of generating electricity by converting the sunlight into electricity by using semiconductors [69]. According to ASEAN Remap study conducted by ASEAN Centre of Energy and International Renewable Energy Agency, Malaysia's total installed power generation capacity from solar PV is targeted to hit $5800 \mathrm{MW}$ by 2025 [70]. Thus, based on these two alternative energy sources, impact assessment is conducted using the $\mathrm{SimaPro}^{\circ}$ software to study the impact generated by these three energy sources in supplying $1 \mathrm{kWh}$ of electricity. Figure 5 summarizes the resulting impacts of the three energy options used.

In the category of climate change, it is worth noting that hydro and PV energy contribute to lower impacts compared to the current electricity consumed in Malaysia at 15 and $10 \%$ respectively. To produce $1 \mathrm{kWh}$ of electricity, hydropower consumption contributed 0.13 $\mathrm{kg} \mathrm{CO}$-equivalent while PV energy contributed $0.085 \mathrm{~kg}$ of $\mathrm{CO}_{2}$-equivalent. This is because both alternate sources do not need to supply electricity from the burning of fossil fuels that releases a lot of $\mathrm{CO}_{2}$.

For the category of terrestrial acidification, hydro power contributes a low impact value of $0.65 \%(2.15 \times$ $10^{-5} \mathrm{~kg} \mathrm{SO}_{2}$-equivalent) as compared to existing electricity use. While PV energy has contributed $4.45 \times 10^{-4} \mathrm{~kg}$ $\mathrm{SO}_{2}$-equivalent, e.g., $13.4 \%$ compared to electricity from fossil fuel combustion. In the eutrophication category, hydropower and PV energy resulted in low impact compared to electricity from fossil combustion, e.g., 1.4 and $35.5 \%$ respectively. Fossil combustion releases nitrogen dioxide $\left(\mathrm{NO}_{\mathrm{x}}\right)$ as well as high $\mathrm{SO}_{2}$ emissions.

In the category of toxicity to humans, PV energy has generated the greatest impact, by releasing a $1,4-\mathrm{dB}$ equivalent $0.00704 \mathrm{~kg}$ in supplying $1 \mathrm{kWh}$ of electricity. This is due to chemicals found in PV cells such as cadmium telluride, copper indium selenide and cadmium gallium that release toxic substances into the environment. In conclusion, this analysis suggests that existing electrical energy contributes to majority of the environmental impacts, thus a sustainable aerobically-digested POME treatment system can be developed with the use of renewable energy. Therefore, shifting of fossil fuel towards renewable energy is crucial in preserving the environment.

\section{Conclusions}

The LCA of different combinations of the integrated membrane-filtration system was based on the four main life cycle impact categories (climate change, terrestrial acidification, eutrophication, and human toxicity) through the input from electricity consumption, utilization of process water, and use of $\mathrm{NaOH}$. It can be concluded that electricity consumption is the dominant factor contributing to most of the life cycle impact

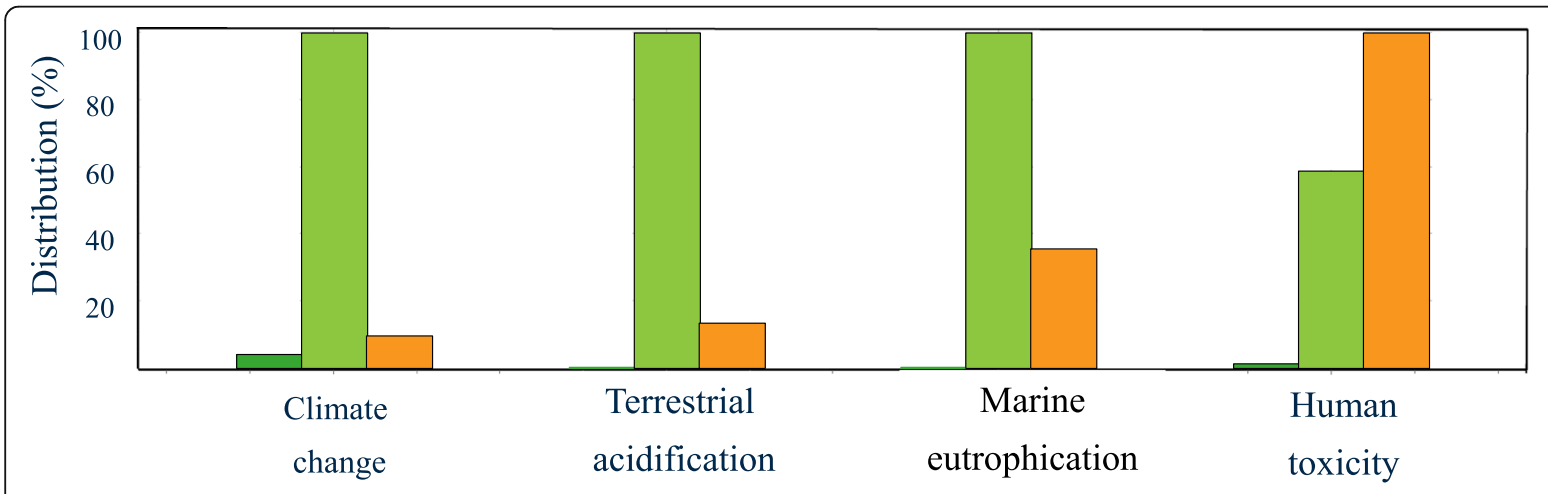

Electricity, high voltage $\{\mathrm{MY}\}$ electricity production, hydro, reservoir, tropical region $\mid$ Alloc Def, S

Electricity, medium voltage $\{M Y\}$ electricity voltage transformation from high to medium voltage $\mid$ Alloc Def, S

Electricity, low voltage $\{\mathrm{MY}\}$ electricity production, photovoltaic, $3 \mathrm{kWp}$ slated-roof installation, multi-Si, panel, mounted $\mid$ Alloc Def, S

Fig. 5 Contribution of alternatives of electricity production towards life cycle impact categories 
categories $(50.2-77 \%)$ as the emissions of $\mathrm{CO}_{2}, \mathrm{SO}_{2}$, nitrogen oxides, and volatile mercury during the combustion of fossil fuels in electricity generation lead to climate change, terrestrial acidification, eutrophication, and human toxicity. Therefore, among the combinations of operating process, Combination I system which involves all unit operations with high electricity consumption $(52 \mathrm{MJ})$ registers the greatest impact towards all impact categories. On the other hand, Combination IV system is the most environmentally-friendly for treating aerobically-digested POME in achieving $6 \mathrm{~m}^{3}$ of boiler feed grade treated water, since it involves only two unit operations - the pre-treatment unit comprising sand filters and activated carbon filters and $\mathrm{RO}$ membrane unit - with the least electricity consumption (41.6 MJ). Electricity consumption registers the highest impact towards all life cycle impact categories: $73 \%$ on climate change, $80 \%$ on terrestrial acidification, $51 \%$ on eutrophication, and $43 \%$ on human toxicity. Combination IV has reduced the electricity consumption by $20 \%$ which contributing to most of impact categories. However, the LCA herein focuses on only the operational phase and excludes the construction and disposal phases. Further studies examining those phases are therefore suggested.

\section{Supplementary Information}

The online version contains supplementary material available at https://doi. org/10.1186/s42834-021-00089-5.

Additional file 1: Fig. S1. P\&ID of the pilot-scale integrated membranefiltration system. Fig. S2. Combination I of integrated membranefiltration system contribution towards climate change. Fig. S3. Combination I of integrated membrane-filtration system contribution towards terrestrial acidification. Fig. S4. Combination I of integrated membranefiltration system contribution towards eutrophication. Fig. S5. Combination I of integrated membrane-filtration system contribution towards human toxicity. Fig. S6. Combination II of integrated membrane-filtration system contribution towards climate change. Fig. S7. Combination II of integrated membrane-filtration system contribution towards terrestrial acidification. Fig. S8. Combination II of integrated membrane-filtration system contribution towards eutrophication. Fig. S9. Combination II of integrated membrane-filtration system contribution towards human toxicity. Fig. S10. Combination III of integrated membrane-filtration system contribution towards climate change. Fig. S11. Combination III of integrated membrane-filtration system contribution towards terrestrial acidification. Fig. S12. Combination III of integrated membrane-filtration system contribution towards eutrophication. Fig. S13. Combination III of integrated membrane-filtration system contribution towards human toxicity. Fig. S14. Combination IV of integrated membrane-filtration system contribution towards climate change. Fig. S15. Combination IV of integrated membrane-filtration system contribution towards terrestrial acidification. Fig. S16. Combination IV of integrated membrane-filtration system contribution towards eutrophication. Fig. S17. Combination IV of integrated membrane-filtration system contribution towards human toxicity.

\section{Acknowledgements}

The authors wish to gratefully acknowledge the funding for this work by Dana Modal Insan (MI-2019-017) and Geran Universiti Penyelidikan (GUP2017-098)

\section{Authors' contributions}

Ho Kah Chun provides data for the study, Chong Meng Teck conducted LCA study, Teow Yeit Haan analyzed and interpreted the data and written the manuscript, and Abul Wahab Mohammad provides consultation advice for the project. The author(s) read and approved the final manuscript.

\section{Funding}

This work was supported by Dana Modal Insan (MI-2019-017) and Geran Universiti Penyelidikan (GUP-2017-098).

\section{Availability of data and materials}

The data sets used and/or analyzed during the current study are available from the corresponding author on reasonable request.

\section{Declarations}

\section{Competing interests}

The authors declare they have no competing interests.

\section{Author details}

${ }^{1}$ Department of Chemical and Process Engineering, Universiti Kebangsaan Malaysia, 43600 Bangi, Malaysia. ${ }^{2}$ Research Centre for Sustainable Process Technology, Universiti Kebangsaan Malaysia, 43600 Bangi, Malaysia. ${ }^{3}$ Faculty of Engineering, Built Environment, and Information Technology, SEGi University, 437810 Kota Damansara, Malaysia.

Received: 10 July 2020 Accepted: 10 March 2021

Published online: 25 March 2021

\section{References}

1. Islam MS, Baini R, Tanjong SJ, Said MAM, Joy EJ. Effects of hydraulic retention time and solid retention time of POME on COD removal efficiency. Int J Auto Mech Eng 2018;15:5347-55.

2. Madaki YS, Seng L. Palm oil mill effluent (POME) from Malaysia palm oil mills: waste or resource. Int J Sci Environ Technol 2013;2:1138-55.

3. Ho KC, Teow YH, Mohammad AW. Optimization of nanocomposite conductive membrane formulation and operating parameters for electrically-enhanced palm oil mill effluent filtration using response surface methodology. Process Saf Environ 2019;126:297-308.

4. Ndubuisi-Nnaji UU, Ofon UA, Ekponne NI, Offiong NAO. Improved biofertilizer properties of digestate from codigestion of brewer's spent grain and palm oil mill effluent by manure supplementation. Sustain Environ Res 2020;30:14.

5. Johnson D, Lun AW, Mohammed AW, Hilal N. Dewatering of POME digestate using lignosulfonate driven forward osmosis. Sep Purif Technol 2020;235:116151.

6. Ahmad $A L$, Ismail $S$, Bhatia $S$. Water recycling from palm oil mill effluent (POME) using membrane technology. Desalination 2003;157:87-95.

7. Ghani MSH, Haan TY, Lun AW, Mohammad AW, Ngteni R, Yusof KMM. Fouling assessment of tertiary palm oil mill effluent (POME) membrane treatment for water reclamation. J Water Reuse Desal 2018:8:412-23.

8. Narayanan CM, Narayan V. Biological wastewater treatment and bioreactor design: a review. Sustain Environ Res 2019;29:33.

9. Teow YH, Mohammad AW, Wan Mohammad Hamdan WNA, Ghani MSH, Ngteni R, Mohamed Yusof KM. Pilot-scale integrated pretreatment/ membrane filtration system for aerobic palm oil mill effluent (POME) treatment. In: The 2016 World Congress on Advances in Civil, Environmental, and Materials Research. Jeju Island; 2016.

10. Kamble S, Singh A, Kazmi A, Starkl M. Environmental and economic performance evaluation of municipal wastewater treatment plants in India: a life cycle approach. Water Sci Technol 2019;79:1102-12.

11. Meneses YE, Flores RA. Feasibility, safety, and economic implications of whey-recovered water in cleaning-in-place systems: a case study on water conservation for the dairy industry. J Dairy Sci 2016;99:3396-407.

12. Sharvini SR, Noor ZZ, Chong CS, Stringer LC, Glew D. Energy generation from palm oil mill effluent: a life cycle assessment of two biogas technologies. Energy 2020;191:116513.

13. Stichnothe $H$, Schuchardt F. Comparison of different treatment options for palm oil production waste on a life cycle basis. Int J Life Cycle Ass 2010;15: 907-15 
14. Norhasmillah AH, Puah CW, Ibrahim NA, Baharuddin AS, Choo YM. Life cycle inventory of the commercial production of compost from oil palm biomass: a case study. Environ Dev Sustain 2013;15:1663-70.

15. Garcia-Nunez JA, Rodriguez DT, Fontanilla CA, Ramirez N, Lora EE, Frear CS, et al. Evaluation of alternatives for the evolution of palm oil mills into biorefineries. Biomass Bioenerg 2016;95:310-29.

16. Nasution MA, Wibawa DS, Ahamed T, Noguchi R. Comparative environmental impact evaluation of palm oil mill effluent treatment using a life cycle assessment approach: a case study based on composting and a combination for biogas technologies in North Sumatera of Indonesia. J Clean Prod 2018;184:1028-40.

17. Chong WC, Chung YT, Teow YH, Zain MM, Mahmoudi E, Mohammad AW. Environmental impact of nanomaterials in composite membranes: life cycle assessment of algal membrane photoreactor using polyvinylidene fluoride composite membrane. J Clean Prod 2018;202:591-600.

18. Abu Bakar SNH, Abu Hasan H, Mohammad AW, Abdullah SRS, Haan TY, Ngteni $R$, et al. A review of moving-bed biofilm reactor technology for palm oil mill effluent treatment. J Clean Prod 2018;171:1532-45.

19. Teow YH, Ghani MSH, Mohammad AW. Physical and chemical cleaning for nanofiltration/reverse osmosis (NF/RO) membranes in treatment of tertiary palm oil mill effluent (POME) for water reclamation. J Kejuruteraan 2018;1:51-8.

20. Ciroth A. Goal and scope connection to the interpretation phase. In: Curran MA, editor. Goal and scope definition in life cycle assessment. Dordrecht: Springer; 2017. 161-7.

21. Laca A, Herrero M, Diaz M. Life cycle assessment in biotechnology: In: Young MM, editor. Comprehensive biotechnology. 2nd ed. Amsterdam: Elsevier; 2011. 839-51.

22. Lundie S, Peters GM, Beavis PC. Life cycle assessment for sustainable metropolitan water systems planning. Environ Sci Technol 2004:38:3465-73.

23. Raluy RG, Serra L, Uche J. Life cycle assessment of water production technologies - Part 1: life cycle assessment of different commercial desalination technologies (MSF, MED, RO). Int J Life Cycle Ass 2005;10:285-93.

24. Norfaradila J, Norela S, Salmijah S, Ismail BS. Life cycle assessment (LCA) for the production of palm biodiesel: a case study in Malaysia and Thailand. Malays Appl Biol 2014;43:53-63.

25. Gelowitz MDC, McArthur JJ. Insights on environmental product declaration use from Canada's first LEED ${ }^{\oplus}$ v4 platinum commercial project. Resour Conserv Recy 2018;136:436-44.

26. Halimah M, Tan YA, Sasha KNN, Zuriati Z, Rawaida Al, Choo YM. Determination of life cycle inventory and greenhouse gas emissions for a selected oil palm nursery in Malaysia: a case study. J Oil Palm Res 2013;25:343-7.

27. Goedkoop M, Heijungs R, Huijbregts M, De Schryver A, Struijs J, van Zelm R. ReCiPE 2008: a life cycle impact assessment method which comprises harmonised category indicators at the midpoint and the endpoint level. The Hague: Ministry of Housing, Spatial Planning and Environment; 2013.

28. VU. Towards a life cycle impact assessment method which comprises category indicators at the midpoint and the endpoint level. Report of the first project phase: design of the new method. Amsterdam: Vrije Universiteit Amsterdam; 2003.

29. Yi S, Kurisu KH, Hanaki K. Application of LCA by using midpoint and endpoint interpretations for urban solid waste management. J Environ Prot 2014;5:1091-103.

30. Taahira G. A comparative life cycle assessment (LCA) of water treatment plants using alternative sources of water (seawater and mine affected water) [Master's Thesis]. Durban: University of KwaZulu-Natal; 2016.

31. Nasution MA, Wulandari A, Ahamed T, Noguchi R. Alternative POME treatment technology in the implementation of roundtable on sustainable palm oil, Indonesian sustainable palm oil (ISPO), and Malaysian sustainable palm oil (MSPO) standards using LCA and AHP methods. Sustainability-Basel 2020;12:4101.

32. Achten WMJ, Vandenbempt $P$, Almeida J, Mathijs E, Muys B. Life cycle assessment of a palm oil system with simultaneous production of biodiesel and cooking oil in Cameroon. Environ Sci Technol 2010;44:4809-15.

33. Jensen AA, Hoffman L, Møller BT, Schmidt A, dk-TEKNIK Energy \& Environment, Christiansen $K$, et al. Life cycle assessment (LCA): a guide to approaches, experiences and information sources. Copenhagen: European Environment Agency; 1997

34. Pan YR, Wang X, Ren ZJ, Hu CZ, Liu JX, Butler D. Characterization of implementation limits and identification of optimization strategies for sustainable water resource recovery through life cycle impact analysis. Environ Int 2019;133:105266.
35. Huijbregts MAJ, Steinmann ZJN, Elshout PMF, Stam G, Verones F, Vieira $M$, et al. ReCiPe2016: a harmonised life cycle impact assessment method at midpoint and endpoint level. Int J Life Cycle Ass 2017;22: 138-47.

36. Huntingford C, Lowe JA, Howarth N, Bowerman NHA, Gohar LK, Otto A, et al. The implications of carbon dioxide and methane exchange for the heavy mitigation RCP2.6 scenario under two metrics. Environ Sci Policy 2015;51:77-87.

37. ST. Malaysia energy statistics handbook 2017. Putrajaya: Energy Commission; 2017.

38. Mahlia TMI. Emissions from electricity generation in Malaysia. Renew Energ 2002:27:293-300.

39. Macedonio F, Drioli E. Membrane engineering for green process engineering. Engineering 2017;3:290-8

40. Rothausen SGSA, Conway D. Greenhouse-gas emissions from energy use in the water sector. Nat Clim Change 2011:1:210-9.

41. Kyung D, Kim D, Park N, Lee W. Estimation of $\mathrm{CO}_{2}$ emission from water treatment plant - model development and application. J Environ Manage 2013;131:74-81.

42. Sbardella L, Comas J, Fenu A, Rodriguez-Roda I, Weemaes M. Advanced biological activated carbon filter for removing pharmaceutically active compounds from treated wastewater. Sci Total Environ 2018:636:519-29.

43. Van Damme M, Clarisse L, Heald CL, Hurtmans D, Ngadi Y, Clerbaux C, et al. Global distributions, time series and error characterization of atmospheric ammonia $\left(\mathrm{NH}_{3}\right)$ from IASI satellite observations. Atmos Chem Phys 2014;14:2905-22.

44. Paulot F, Jacob DJ, Pinder RW, Bash JO, Travis K, Henze DK. Ammonia emissions in the United States, European Union, and China derived by highresolution inversion of ammonium wet deposition data: interpretation with a new agricultural emissions inventory (MASAGE_NH ${ }_{3}$ ). J Geophys ResAtmos 2014;119:4343-64.

45. Rewlay-ngoen C, Papong S, Sampattagul S. The NPP and social asset impacts of acidification from coal-fired power plant in Thailand. Enrgy Proced 2014;52:234-41.

46. Burcharth HF, Hawkins SJ, Zanuttigh B, Lamberti A. Environmental design guidelines for low crested coastal structures. Amsterdam: Elsevier; 2007.

47. Munawer ME. Human health and environmental impacts of coal combustion and post-combustion wastes. J Sustain Min 2018;17:87-96.

48. WBG. Pollution prevention and abatement handbook 1998: towards cleaner production. Washington, DC: The World Bank Group; 1999.

49. Yee LF, Abdullah P, Ata S, Abdullah A, Ishak B, Nidzham K. Chlorination and chloramines formation. Malaysian J Anal Sci 2008;12:528-35.

50. USEPA. 2012 Guidelines for water reuse. Washington, DC: US Environmental Protection Agency; 2012

51. Wang ZH, Li SX. Nitrate $N$ loss by leaching and surface runoff in agricultural land: a global issue (a review). Adv Agron 2019;156:159-217.

52. Al-Thawadi FE, Al-Ghamdi SG. Evaluation of sustainable urban mobility using comparative environmental life cycle assessment: a case study of Qatar. Transp Res Interdi Persp 2019;1:100003.

53. USEPA. Compilation of air pollutant emission factors. Volume 1. Stationary point and area sources. 5th ed. Research Triangle Park: US Environmental Protection Agency; 1995

54. Winalski D, Mayson S, Savitz J. Poison plants: chlorine factories are a major global source of mercury. Washington DC: OCEANA; 2005.

55. Hong YS, Kim YM, Lee KE. Methylmercury exposure and health effects. J Prev Med Public Health 2012;45:353-63.

56. Ayres R. The life-cycle of chlorine, part l: chlorine production and the chlorine-mercury connection. J Ind Ecol 1997;1:81-94.

57. Matta G, Gjyli L. Mercury, lead and arsenic: impact on environment and human health. J Chem Pharm Sci 2016;9:718-25

58. Kampa M, Castanas E. Human health effects of air pollution. Environ Pollut 2008:151:362-7.

59. Hidayu AR, Mohamad NF, Matali S, Sharifah ASAK. Overview of mercury removal from flue gas using activated carbon. In: 2013 IEEE Business Engineering and Industrial Applications Colloquium. Langkawi; 2013.

60. Poulopoulos SG, Inglezakis VJ, editors. Environment and development: basic principles, human activities, and environmental implications. Amsterdam: Elsevier; 2016.

61. Wang S, Parajuli S, Sivalingam V, Bakke R. Biofilm in moving bed biofilm process for wastewater treatment. In: Dincer S, Ozdenefe MS, Arkut A editors. Bacterial biofilms. London: IntechOpen; 2019. 1-15.

62. Brown LH, Buettner PG, Canyon DV. The energy burden and environmental impact of health services. Am J Public Health 2012;102:e76-82. 
63. Paletto A, Bernardi S, Pieratti E, Teston F, Romagnoli M. Assessment of environmental impact of biomass power plants to increase the social acceptance of renewable energy technologies. Heliyon 2019;5:e02070.

64. Hou D, He J, Lu C, Sun Y, Zhang F, Otgonbayar K. Effects of environmental factors on nutrients release at sediment-water interface and assessment of trophic status for a typical shallow lake, northwest China. Sci World J 2013; 2013:716342.

65. USBR. Reclamation: managing water in the west. Washington, DC: US Bureau of Reclamation; 2007.

66. ST. Malaysia energy statistics handbook 2015. Putrajaya: Energy Commission; 2015.

67. Sovacool BK, Bulan LC. Energy security and hydropower development in Malaysia: the drivers and challenges facing the Sarawak Corridor of Renewable Energy (SCORE). Renew Energ 2012;40:113-29.

68. IEA. Southeast Asia Energy Outlook 2019. Paris: International Energy Agency; 2019.

69. Kasap S, Capper P, editors. Springer handbook of electronic and photonic materials. 2nd ed. Cham: Springer; 2017.

70. IRENA, ACE. Renewable Energy Outlook for ASEAN: a REmap Analysis. Abu Dhabi and Jakarta: International Renewable Energy Agency and ASEAN Centre for Energy; 2016.

\section{Publisher's Note}

Springer Nature remains neutral with regard to jurisdictional claims in published maps and institutional affiliations.

Ready to submit your research? Choose BMC and benefit from:

- fast, convenient online submission

- thorough peer review by experienced researchers in your field

- rapid publication on acceptance

- support for research data, including large and complex data types

- gold Open Access which fosters wider collaboration and increased citations

- maximum visibility for your research: over $100 \mathrm{M}$ website views per year

At $\mathrm{BMC}$, research is always in progress.

Learn more biomedcentral.com/submissions 